\title{
Supporting Information \\ Optimization of Two-Stage Pressure/Vacuum Swing Adsorption with Variable Dehydration Level for Post-Combustion Carbon Capture
}

\begin{abstract}
Karson T. Leperi, Randall Q. Snurr*, Fengqi You*
Department of Chemical and Biological Engineering, Northwestern University, Evanston, IL 60208 USA

\section{P/VSA Simulation and Isotherm Parameters}

The $\mathrm{CO}_{2}, \mathrm{~N}_{2}$, and the $\mathrm{H}_{2} \mathrm{O}$ isotherm parameters for all of the materials, along with the operating variables used in the simulations are provided below.
\end{abstract}

Table S1. Operating variables for the P/VSA simulations

\begin{tabular}{|c|c|}
\hline$\varepsilon$ & 0.37 \\
\hline $\mathrm{r}_{\mathrm{p}}[\mathrm{mm}]$ & 1 \\
\hline $\mathrm{k}_{\mathrm{co} 2}\left[\mathrm{~s}^{-1}\right]$ & 0.1631 \\
\hline $\mathrm{k}_{\mathrm{N} 2}\left[\mathrm{~s}^{-1}\right]$ & 0.2044 \\
\hline$\rho_{\mathrm{w}}\left[\mathrm{kg} / \mathrm{m}^{3}\right]$ & 7800 \\
\hline $\mathrm{C}_{\mathrm{p}, \mathrm{a}}[\mathrm{J} / \mathrm{mol} / \mathrm{K}]$ & 30.7 \\
\hline $\mathrm{C}_{\mathrm{p}, \mathrm{g}}[\mathrm{J} / \mathrm{mol} / \mathrm{K}]$ & 30.7 \\
\hline $\mathrm{C}_{\mathrm{p}, \mathrm{s}}[\mathrm{J} / \mathrm{kg} / \mathrm{K}]$ & 1070 \\
\hline $\mathrm{C}_{\mathrm{p}, \mathrm{w}}[\mathrm{J} / \mathrm{kg} / \mathrm{K}]$ & 502 \\
\hline$\mu\left[\mathrm{Pa}^{*} \mathrm{~s}\right]$ & $1.72 \times 10^{-5}$ \\
\hline $\mathrm{D}_{\mathrm{m}}\left[\mathrm{m}^{2} / \mathrm{s}\right]$ & $1.2995 \times 10^{-5}$ \\
\hline $\mathrm{K}_{\mathrm{z}}[\mathrm{W} / \mathrm{m} / \mathrm{K}]$ & 0.09 \\
\hline $\mathrm{K}_{\mathrm{w}}[\mathrm{W} / \mathrm{m} / \mathrm{K}]$ & 16 \\
\hline $\mathrm{h}_{\mathrm{in}}\left[\mathrm{W} / \mathrm{m}^{2} / \mathrm{K}\right]$ & 8.6 \\
\hline $\mathrm{h}_{\text {out }}\left[\mathrm{W} / \mathrm{m}^{2} / \mathrm{K}\right]$ & 2.5 \\
\hline $\mathrm{T}_{0}[\mathrm{~K}]$ & 313 \\
\hline $\mathrm{T}_{\mathrm{a}}[\mathrm{K}]$ & 298 \\
\hline $\mathrm{u}_{0}[\mathrm{~m} / \mathrm{s}]$ & 1 \\
\hline $\mathrm{q}_{\mathrm{s} 0}[\mathrm{~mol} / \mathrm{kg}]$ & 5.84 \\
\hline
\end{tabular}

Table S2. Densities of the four adsorbents

\begin{tabular}{|l|l|l|l|l|}
\hline Material & Zeolite 13X & Zeolite 5A & HKUST-1 & Ni-MOF-74 \\
\hline$\rho_{\mathrm{s}}\left[\mathrm{kg} / \mathrm{m}^{3}\right]$ & 1130 & 1130 & 881 & 1195 \\
\hline
\end{tabular}


Table S3. Isotherm parameters for $\mathrm{CO}_{2}$ and $\mathrm{N}_{2}$ for zeolite 5A, HKUST-1 and Ni-MOF-74.

\begin{tabular}{c|cccccc}
\hline Parameter & \multicolumn{2}{|c}{ Zeolite 5A } & \multicolumn{2}{c}{ HKUST-1 } & \multicolumn{2}{c}{ Ni-MOF-74 } \\
\hline Component & $\mathrm{CO}_{2}$ & $\mathrm{~N}_{2}$ & $\mathrm{CO}_{2}$ & $\mathrm{~N}_{2}$ & $\mathrm{CO}_{2}$ & $\mathrm{~N}_{2}$ \\
\hline $\mathrm{b}_{\mathrm{i}}\left[\mathrm{kPa}^{-1}\right]$ & $1.41 \times 10^{-7}$ & $3.71 \times 10^{-7}$ & $6.84 \times 10^{-8}$ & $6.81 \times 10^{-7}$ & $4.47 \times 10^{-8}$ & $1.40 \times 10^{-7}$ \\
$\mathrm{~d}_{\mathrm{i}}\left[\mathrm{kPa}^{-1}\right]$ & 0.00 & 0.00 & $4.52 \times 10^{-6}$ & 0.00 & $4.71 \times 10^{-10}$ & 0.00 \\
$\mathrm{q}_{\mathrm{b}, \mathrm{i}}[\mathrm{mol} / \mathrm{kg}]$ & 3.4 & 3.30 & 12.4 & 8.00 & 6.21 & 11.9 \\
$\mathrm{q}_{\mathrm{d}, \mathrm{i}}[\mathrm{mol} / \mathrm{kg}]$ & 0.00 & 0.00 & 1.16 & 0.00 & 7.15 & 0.00 \\
$\Delta \mathrm{U}_{\mathrm{b}, \mathrm{i}}[\mathrm{kJ} / \mathrm{mol}]$ & -37.4 & -19.4 & -25.7 & -12.5 & -37.8 & -19.4 \\
$\Delta \mathrm{U}_{\mathrm{d}, \mathrm{i}}[\mathrm{kJ} / \mathrm{mol}]$ & 0.00 & 0.00 & -25.7 & 0.00 & -37.8 & 0.00 \\
\hline
\end{tabular}

Table S4. Isotherm parameters for $\mathrm{CO}_{2}$ and $\mathrm{N}_{2}$ for zeolite $13 \mathrm{X}$.

\begin{tabular}{c|cc}
\hline Parameter & $\mathrm{CO}_{2}$ & $\mathrm{~N}_{2}$ \\
\hline $\mathrm{b}_{\mathrm{i}}\left[\mathrm{m}^{3} / \mathrm{mol}\right]$ & $8.65 \times 10^{-7}$ & $2.50 \times 10^{-6}$ \\
$\mathrm{~d}_{\mathrm{i}}\left[\mathrm{m}^{3} / \mathrm{mol}\right]$ & $2.63 \times 10^{-8}$ & 0.00 \\
$\mathrm{q}_{\mathrm{b}, \mathrm{i}}[\mathrm{mol} / \mathrm{kg}]$ & 3.09 & 5.84 \\
$\mathrm{q}_{\mathrm{d}, \mathrm{i}}[\mathrm{mol} / \mathrm{kg}]$ & 2.54 & 0.00 \\
$\Delta \mathrm{U}_{\mathrm{b}, \mathrm{i}}[\mathrm{kJ} / \mathrm{mol}]$ & -36.6 & -15.8 \\
$\Delta \mathrm{U}_{\mathrm{d}, \mathrm{i}}[\mathrm{kJ} / \mathrm{mol}]$ & -35.7 & 0.00
\end{tabular}

* In the dual-site Langmuir isotherms, $\mathrm{q}_{\mathrm{b}, \mathrm{i}}$ and $\mathrm{q}_{\mathrm{d}, \mathrm{i}}$ are the saturation loadings of component $\mathrm{i}$ for the first and second sites, respectively, $\Delta \mathrm{U}_{\mathrm{b}, \mathrm{i}}$ and $\Delta \mathrm{U}_{\mathrm{d}, \mathrm{i}}$ are the heats of adsorption for component $\mathrm{i}$ for the first and second sites, respectively, and $b_{i}$ and $\mathrm{d}_{\mathrm{i}}$ are the isotherm parameters for component $i$ for the first and second sites, respectively.

Table S5. Water isotherm parameters and impact parameters.

Zeolite 13X

\begin{tabular}{|c|c|c|c|c|c|}
\hline Parameters & $\mathrm{a}[\mathrm{mol} / \mathrm{kg} / \mathrm{kPa}]$ & $\mathrm{b}\left[\mathrm{kPa}^{-1}\right]$ & $\mathrm{t}[-]$ & & $\mathrm{c}[\mathrm{kg} / \mathrm{mol}]$ \\
\hline Values & 35000 & 2333 & 0.383 & & 0.337 \\
\hline \multicolumn{6}{|c|}{ Zeolite 5A } \\
\hline Parameters & $\mathrm{a}[\mathrm{mol} / \mathrm{kg} / \mathrm{kPa}]$ & $\mathrm{b}\left[\mathrm{kPa}^{-1}\right]$ & $\mathrm{t}[-]$ & & $\mathrm{c}[\mathrm{kg} / \mathrm{mol}]$ \\
\hline Values & $3.56 \times 10^{6}$ & $1.52 \times 10^{5}$ & 0.18 & & 0.337 \\
\hline \multicolumn{6}{|c|}{ Ni-MOF-74 } \\
\hline Parameters & $\mathrm{q}_{\mathrm{b}}[\mathrm{mol} / \mathrm{kg}]$ & $\mathrm{b}\left[\mathrm{kPa}^{-1}\right]$ & $\mathrm{q}_{\mathrm{d}}[\mathrm{mol} / \mathrm{kg}]$ & $\mathrm{d}\left[\mathrm{kPa}^{-1}\right]$ & $\mathrm{c}[\mathrm{kg} / \mathrm{mol}]$ \\
\hline Values & 27.7 & 16.42 & 0.975 & 0.27 & 0.142 \\
\hline \multicolumn{6}{|c|}{ HKUST-1 } \\
\hline Parameters & $\mathrm{a}\left[\mathrm{kPa}^{-5}\right]$ & $\mathrm{c}\left[\mathrm{kPa}^{-3}\right]$ & $\mathrm{d}\left[\mathrm{kPa}^{-2}\right]$ & $\mathrm{e}\left[\mathrm{kPa}^{-1}\right]$ & $\mathrm{c}[\mathrm{kg} / \mathrm{mol}]$ \\
\hline Values & 0.132 & 13.5 & -33.5 & 35.9 & 0.095 \\
\hline
\end{tabular}




\section{Process Objective Equations}

The following equations are used to calculate the purity, recovery and mass balance of each stage.

$$
\begin{aligned}
& \text { moles }_{\mathrm{CO}_{2}, \text { out depr }}=\frac{P_{0} L}{R T_{0}} \varepsilon A \int_{0}^{\tau_{\text {depr }}} \bar{u}_{z} y_{\mathrm{CO}_{2}} \frac{\bar{P}}{\bar{T}} d \tau \quad \forall Z=0^{+} \\
& \text {moles }_{\mathrm{CO}_{2}, \text { out pur }}=\frac{P_{0} L}{R T_{0}} \varepsilon A \int_{0}^{\tau_{\text {pur }}} \bar{u}_{z} y_{\mathrm{CO}_{2}} \frac{\bar{P}}{\bar{T}} d \tau \quad \forall Z=0^{+} \\
& \text {moles }_{\text {total,out } \mid d e p r}=\frac{P_{0} L}{R T_{0}} \varepsilon A \int_{0}^{\tau_{d e p r}} \overline{u_{z}} \frac{\bar{P}}{\bar{T}} d \tau \quad \forall Z=0^{+} \\
& \text {moles }_{\text {total,outpur }}=\frac{P_{0} L}{R T_{0}} \varepsilon A \int_{0}^{\tau_{p u r}} \bar{u}_{z} \frac{\bar{P}}{\bar{T}} d \tau \quad \forall Z=0^{+} \\
& \text {moles }_{\mathrm{CO}_{2}, \text { out } \mathrm{|ads}}=\frac{P_{0} L}{R T_{0}} \varepsilon A \int_{0}^{\tau_{a d s}} \bar{u}_{z} y_{\mathrm{CO}_{2}} \frac{\bar{P}}{\bar{T}} d \tau \quad \forall Z=1^{-} \\
& \text {moles }_{\mathrm{CO}_{2}, \mathrm{in} \mid a d s}=\frac{P_{0} L}{R T_{0}} \varepsilon A \int_{0}^{\tau_{a d s}} \bar{u}_{z} y_{\mathrm{CO}_{2}} \frac{\bar{P}}{\bar{T}} d \tau \quad \forall Z=0^{+} \\
& \text {moles }_{\mathrm{CO}_{2}, \mathrm{in} \mid p r}=\frac{P_{0} L}{R T_{0}} \varepsilon A \int_{0}^{\tau_{p r}} \bar{u}_{z} y_{\mathrm{CO}_{2}} \frac{\bar{P}}{\bar{T}} d \tau \quad \forall Z=0^{+} \\
& \operatorname{moles}_{\mathrm{CO}_{2}, \text { in } \mid \mathrm{pur}}=\frac{P_{0} L}{R T_{0}} \varepsilon A \int_{0}^{\tau_{\text {pur }}} \bar{u}_{z} y_{\mathrm{CO}_{2}} \frac{\bar{P}}{\bar{T}} d \tau \quad \forall Z=1^{-} \\
& \text {Pur }=\frac{\text { moles }_{\mathrm{CO}_{2}, \text { out depr }}+\text { moles }_{\mathrm{CO}_{2}, \text { out } \mid \text { pur }}}{\text { moles }_{\text {total }, \text { out } \mid \text { depr }}+\text { moles }_{\text {total }, \text { out } \mid \text { pur }}} \\
& \text { Rec }=1-\frac{\text { moles }_{\mathrm{CO}_{2}, \text { outlads }}}{\text { moles }_{\mathrm{CO}_{2}, \text { in } \mid \text { pres }}+\text { moles }_{\mathrm{CO}_{2}, \text { in|ads }}} \\
& \text { Mass Balance }=\frac{\text { moles }_{\mathrm{CO}_{2}, \text { out depr }}+\text { moles }_{\mathrm{CO}_{2}, \text { out|pur }}+\text { moles }_{\mathrm{CO}_{2}, \text { out } \mid \text { ads }}}{\text { moles }_{\mathrm{CO}_{2}, \text { in } \mid \text { pres }}+\text { moles }_{\mathrm{CO}_{2}, \text { in } \mid \text { ads }}+\text { moles }_{\mathrm{CO}_{2}, \mathrm{in} \mid \mathrm{p} u r}}
\end{aligned}
$$




\section{Economic Equations}

The total annualized cost (TAC) of the P/VSA system, dehydration technology and the post separation compression is calculated as followed:

$$
\mathrm{TAC}=\mathrm{ACC}+\mathrm{AOC}+\mathrm{PSCC}+\mathrm{DC}
$$

where ACC and AOC are the Annualized Capital Cost and Annualized Operating Cost of the P/VSA system, PSCC is the overall annual cost of the post separation compression (PSC) system, and DC is the overall annual dehydration cost. The cost parameters used in the economic evaluation can be found in Table S6.

Table S6. Economic Parameters used in the economic calculations

\begin{tabular}{|l|l|}
\hline Interest Rate & $10 \%$ \\
\hline Life Span of Equipment & 20 years \\
\hline Cost of TEG & $\$ 2000 /$ ton \\
\hline Cost of Electricity & $\$ 0.06 / \mathrm{kWh}$ \\
\hline Operating Time & 8000 hours $/$ year \\
\hline Cost of Cooling Water & $\$ 0.02 / \mathrm{m}^{3}$ \\
\hline Cost of Natural Gas & $\$ 4.76 / \mathrm{MMBtu}$ \\
\hline Cost of Chilled Water & $\$ 4 / \mathrm{GJ}$ \\
\hline
\end{tabular}

\section{P/VSA System}

The annualized capital cost is defined as:

$$
\mathrm{ACC}=\sum_{j}\left(\phi_{\text {equip }} C_{b m, e q u i p, j}+\phi_{a d s o r b} C_{a d s o r b, j}+M C_{j}\right)
$$

where $\phi_{\text {equip }}$ and $\phi_{a d s o r b}$ are the annualization factors for the equipment and adsorbents, respectively, $C_{b m, e q u i p, j}$ is the bare module cost for the equipment and $C_{a d s o r b, j}$ is the cost of the adsorbent. The maintenance cost is assumed to be equal to $5 \%$ of the annualized equipment costs.

The equipment cost is calculated as follows:

$$
C_{b m, e q u i p . j}=N_{c o l, j}\left(F_{b m, c o m p} C_{p, c o m p, j}+F_{b m, v a c} C_{p, v a c, j}+F_{b m, c o l} C_{p, c o l, j}\right)
$$

where $F_{b m}$ is the bare module factor for each piece of equipment and $C_{p, c o m p}, C_{p, v a c}$ and $C_{p, c o l}$ are the purchase cost of the compressor, vacuum pump and column, respectively. We use a bare module factor of 2.15 for the compressors and vacuums and 4.15 for the column.

The purchase cost of the column is calculated using the following equation: 


$$
C_{p, c o l, j}=C_{v, j}+C_{p l, j}+C_{d r, j}
$$

where $C_{v, j}$ is the cost of the vessel for a single column in stage $j$ with a weight of $W_{j}, C_{p l, j}$ is the cost of the platforms and ladders and $C_{d r, j}$ is the cost of the flow distributor. These are calculated as follows:

$$
\begin{gathered}
W_{c o l, j}=\pi\left(2 r_{i n}+t_{c o l}\right)\left(L+1.6 r_{i n}\right) t_{c o l} \rho_{c o l} \\
C_{v, j}=\exp \left[7.0132+0.18255 \ln \left(2.2 W_{c o l, j}\right)+0.02297 \ln \left(2.2 W_{c o l, j}\right)^{2}\right] \\
C_{p l, j}=\left(\left(6.56 r_{i n, j}\right)^{0.7396}\right)\left(\left(3.28 L_{j}\right)^{0.70684}\right) \\
C_{d r, j}=125 \pi\left(3.28 r_{i n, j}\right)^{2}
\end{gathered}
$$

where $L_{j}$ and $r_{i n, j}$ are the length and radius of the columns in stage $j, t_{c o l}$ is the thickness of the column and $\rho_{s}$ is the density of the material. We use carbon steel for the column with a density of $7800 \mathrm{~kg} / \mathrm{m}^{3}$ and a thickness of $0.015 \mathrm{~m}$.

The purchase cost of the vacuum pumps for stage $j, C_{p, v a c, j}$, is calculated as follows:

$$
\begin{gathered}
\dot{Q}_{j}=0.588 \frac{y_{0, j} \operatorname{Rec}_{j} F_{j}}{\operatorname{Pur}_{j}} \frac{R T_{0}}{P_{L, j}} \\
C_{p, v a c, j}=8250\left(\dot{Q}_{j}\right)^{0.35}
\end{gathered}
$$

where $y_{0, j}$ is the mole fraction of $\mathrm{CO}_{2}$ in the feed gas, $R e c_{j}$ is the $\mathrm{CO}_{2}$ recovery, $P u r_{j}$ is the purity of the CO2 product, and $P_{L, j}$ is the purge pressure.

The purchase cost of the compressor, $C_{p, c o m p, j}$, is calculated using the following expressions.

$$
\begin{gathered}
\text { Power }_{a d s, j}=\frac{1}{\eta} R T_{0} F_{j} \frac{\gamma}{\gamma-1}\left[\left(\frac{1.05 P_{0, j}}{P_{a t m}}\right)^{(\gamma-1) / \gamma}-1\right] \\
C_{p, \text { compressor }, j}= \begin{cases}\exp \left[6.8929+0.79 \ln \left(\frac{\text { Power }_{a d s}}{745.7}\right)\right] & \text { if } \mathrm{P}_{0} \leq 2 \mathrm{bar} \\
\exp \left[7.58+0.8 \ln \left(\frac{\text { Power }_{a d s}}{745.7}\right)\right] & \text { if } \mathrm{P}_{0}>2 \text { bar }\end{cases}
\end{gathered}
$$

where $\eta$ is the efficiency of the compressor/vacuum pump. It is noted that either a blower or a compressor is able to perform the compression duties for the P/VSA cycles. If the adsorption pressure is below 2 bar, 
the blower is used with an efficiency of $80 \%$. If the adsorption pressure is above 2 bar, than a compressor with an efficiency of $75 \%$ is used.

The purchase cost of the adsorbent is calculated with the following expression:

$$
\begin{gathered}
C_{p, \text { adsorbent }}=C_{p k} \rho_{s} V_{p} \\
V_{p}=\pi r_{i n}^{2} L
\end{gathered}
$$

where $\mathrm{C}_{\mathrm{pk}}$ is the cost of the adsorbent, $\rho_{\mathrm{s}}$ is the density of the adsorbent and $\mathrm{V}_{\mathrm{p}}$ is the packing volume of the adsorbent.

Finally, the operating cost, $\mathrm{OC}_{\mathrm{j}}$ is calculated as follows:

$$
A O C=\sum_{j} E C\left(W_{p r e s, j}+W_{a d s, j}+W_{d e p r e s s, j}+W_{p u r, j}\right) \frac{8000 \cdot 3600}{t_{c, j}} N_{c o l, j}
$$

where EC is the cost of electricity, $W_{\text {pres }, j}, W_{a d s, j}, W_{\text {depress }, j}$ and $W_{p u r, j}$ are the energy requirements for the pressurization, adsorption, depressurization and purge steps, respectively, and $t_{c, j}$ is the cycle time of stage j. The energy requirements are calculated as follows.

$$
\begin{aligned}
& W_{p r e s, j}= \begin{cases}\frac{1}{\eta} \varepsilon \pi r_{\text {in }}^{2} v_{0} P_{0} \frac{\gamma}{\gamma-1} \int_{0}^{t=t_{\text {pres }}}\left(\left.\bar{v} \bar{P}\right|_{Z=0}\right)\left[\left(\frac{\left.P_{0} \bar{P}\right|_{Z=0}}{P_{f}}\right)^{(\gamma-1) / \gamma}-1\right] d t & \text { if } \mathrm{P}_{z=0} \geq P_{f} \\
0 & \text { if }\left.\mathrm{P}\right|_{z=0}<P_{f}\end{cases} \\
& W_{a d s, j}=\frac{1}{\eta} \varepsilon \pi r_{i n}^{2} v_{0} P_{0} \frac{\gamma}{\gamma-1} \int_{0}^{t=t_{a d s}}\left(\left.\bar{v} \bar{P}\right|_{Z=0}\right)\left[\left(\frac{\left.P_{0} \bar{P}\right|_{Z=0}}{P_{f}}\right)^{(\gamma-1) / \gamma}-1\right] d t \\
& W_{\text {depress }, j}= \begin{cases}\frac{1}{\eta} \varepsilon \pi r_{i n}^{2} v_{0} P_{0} \frac{\gamma}{\gamma-1} \int_{0}^{t=t_{\text {depress }}}\left(\left.\bar{v} \bar{P}\right|_{Z=0}\right)\left[\left(\frac{P_{a t m}}{\left.P_{0} \bar{P}\right|_{Z=0}}\right)^{(\gamma-1) / \gamma}-1\right] d t & \text { if }\left.\mathrm{P}\right|_{z=0} \leq P_{a t m} \\
0 & \text { if }\left.\mathrm{P}\right|_{z=0}>P_{a t m}\end{cases} \\
& W_{p u r, j}=\frac{1}{\eta} \varepsilon \pi r_{i n}^{2} v_{0} P_{0} \frac{\gamma}{\gamma-1} \int_{0}^{t=t_{p u r}}\left(\left.\bar{v} \bar{P}\right|_{Z=0}\right)\left[\left(\frac{P_{a t m}}{\left.P_{0} \bar{P}\right|_{Z=0}}\right)^{(\gamma-1) / \gamma}-1\right] d t
\end{aligned}
$$

\section{Post-Separation Compression}

For calculating the cost of the PSC system, the following equation is used: 


$$
\mathrm{PSCC}=\sum_{1}^{k=5}\left(C_{b m, \text { comp }, k}+A O C_{c o m p, k}\right)+\sum_{1}^{l=6}\left(C_{b m, H E, l}+A O C_{H E, l}\right)+\left(C_{b m, \text { pump }}+A O C_{\text {pump }}\right)
$$

where $C_{b m, c o m p, k}$ and $A O C_{c o m p, \mathrm{k}}$ are the bare module cost for compressor $k, C_{b m, H E, l}$ and $A O C_{H E, l}$ are the bare module cost and operating costs for Heat Exchanger $l$, and $C_{b m, p u m p}$ and $A O C_{\text {pump }}$ are the bare module cost and operating costs for the pump. It is noted that as shown in Figure 1, the PSC section consists of five compressors, six heat exchangers (five using cooling water as the coolant and one using chilled water) and a pump. The bare module cost for each piece of equipment is given as follows:

$$
\begin{aligned}
& C_{b m, \text { comp }}= F_{b m, \text { comp }} F_{\text {mat }, \text { comp }} \exp \left[7.58+0.8 \ln \left(\frac{p_{P S C}}{745.7}\right)\right] \\
& p_{\text {comp }, P S C}= \frac{1}{\eta} \frac{\gamma}{\gamma-1} F_{\text {product }} R T_{0}\left[(2.45)^{\frac{\gamma-1}{\gamma}}-1\right] \\
& C_{b m, H E}= F_{b m, H E} F_{\text {mat }, H E} F_{P, H E} \exp \left[11.147+0.9186 \ln \left(A_{H E}\right)+0.0979 \ln \left(A_{H E}\right)^{2}\right] \\
& C_{b m, \text { pump }}= F_{\text {bm, pump }}\left(F_{\text {mat }, \text { pump }} C_{p, \text { pump }}+C_{p, d r}\right) \\
& C_{p, d r}=\exp \left[5.8259+0.13141 \ln \left(\frac{P_{\text {pump }, P S C}}{\eta_{\text {motor }} \eta_{\text {pump }}}\right)+0.053255 \ln \left(\frac{P_{\text {pump }, P S C}}{\eta_{\text {motor }} \eta_{\text {pump }}}\right)^{2} \ldots\right. \\
&\left.\quad+0.028628 \ln \left(\frac{P_{\text {pump }, P S C}}{\eta_{\text {motor }} \eta_{\text {pump }}}\right)^{3}-0.0035549 \ln \left(\frac{P_{\text {pump }, P S C}}{\eta_{\text {motor }} \eta_{\text {pump }}}\right)^{4}\right] \\
& p_{\text {pump }, P S C}=9.81 Q_{\text {product }} H \rho_{\text {product }, l} \\
& C_{p, \text { pump }}=\exp \left[9.7171-0.6019 \ln \left(Q_{\text {product }} H^{0.5}\right)+0.0519 \ln \left(Q_{\text {product }} H^{0.5}\right)^{2}\right]
\end{aligned}
$$

where $F_{\text {mat }}$ are the material factors for the equipment, $F_{\text {product }}$ is the molar feed rate of the $\mathrm{CO}_{2}$ product stream, $F_{P, H E}$ is the pressure factor for the heat exchangers, $Q_{\text {product }}$ is the volumetric flow rate of the liquid $\mathrm{CO}_{2}$ product, $H$ is the required pump head of the pump $\eta_{\text {motor }}$ and $\eta_{\text {pump }}$ are the efficiencies of the motor and pump, respectively, $\rho_{\text {product } l}$ is the density of the liquid product and $p_{p u m p, p s c}$ is the power requirements from the pump. We assumed that the liquid density of the product is $770 \mathrm{~kg}$ per $\mathrm{m}^{3}$.

The Annualized Operating Costs of the PSC section is calculated as follows: 


$$
\begin{aligned}
& A O C_{\text {comp }, k}=8 p_{P S C} E C \\
& A O C_{H E, l}=C_{c o o l, k} Q_{\text {cool }, k} \\
& A O C_{\text {pump }}=E C \frac{p_{\text {pump }, P S C}}{\eta_{\text {pump }} \eta_{\text {drive }}}
\end{aligned}
$$

where $C_{\text {cool, }, k}$ and $Q_{\text {cool, }, k}$ are the cost and volumetric flow rate requirements of coolant needed for Heat Exchanger $k$.

\section{Dehydration Schemes}

Both the Cooling and Condensing (C\&C) and triethylene absorption (TEG) dehydration schemes are modeled in Aspen HYSYS using the UNIQUAC Fluids package. Based off of the results of the simulations, the annualized cost for each scheme is estimated using cost equations from literature. ${ }^{1}$

For the $\mathrm{C} \& \mathrm{C}$ scheme, the Total Annualized Cost is calculated using the following equation.

$$
T A C_{C \& C}=\left(E C \cdot P_{c o m p}+C W C \cdot Q_{H E}\right)+\left(C_{b m, \text { comp }}+C_{b m, v e s s e l}+\sum_{m} C_{b m, H E, m}\right)
$$

where $P_{\text {comp }}$ is the power requirements of the compressor, $C W C$ is the cost of the cooling water, $Q_{H E}$ is the necessary flow rate of water required by the heat exchangers, and $C_{p, c o m p}, C_{p, H E, m}$ and $C_{p, v e s s e l}$ are the purchase cost of the compressor, the heat exchanger and the vessel. These purchase costs are calculated using the following equations

$$
\begin{gathered}
C_{b m, \text { comp }}=F_{b m, \text { comp }} C_{p, \text { comp }} \\
C_{b m, H E, m}=F_{b m, H E} C_{p, H E, m} \\
C_{b m, \text { vessel }}=F_{b m, \text { vessel }} C_{p, \text { vessel }} \\
\log _{10} C_{p, \text { comp }}=2.2897+1.3604 \log _{10}\left(P_{\text {comp }}\right)-0.1027 \log _{10}\left(P_{\text {comp }}\right)^{2} \\
\log _{10} C_{p, H E, m}=4.8306-0.8509 \log _{10}\left(A_{m}\right)+0.3187 \log _{10}\left(A_{m}\right)^{2} \\
\log _{10} C_{p, \text { vessel }}=3.4974+0.4485 \log _{10}(V)+0.1074 \log _{10}(V)^{2}
\end{gathered}
$$

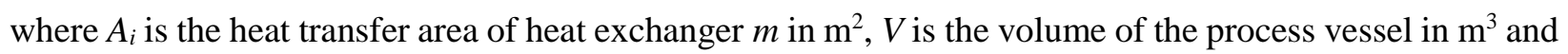
$P_{\text {comp }}$ is in units of $\mathrm{kW}$. We used a bare module factor of 2.27 for the compressor, 3.29 for the heat exchangers and 4.07 for the process vessel.

For the TEG dehydration scheme, the Total Annualized Cost was calculated using the following equation. 


$$
\begin{aligned}
T A C_{T E G}= & \left(E C \cdot P_{\text {pump }}+C W C \cdot Q_{H E}+M U_{T E G} C_{T E G}+H R \cdot C_{N G}\right) \\
& +\left(C_{b m, \text { vessel }}+\sum_{m} C_{b m, H E, m}+C_{b m, \text { pump }}+C_{b m, F H}+\sum_{n} C_{b m, t o w e r, n}\right)
\end{aligned}
$$

where $\mathrm{P}_{\text {pump }}$ is the power requirements of the pump, $\mathrm{MU}_{\mathrm{TEG}}$ is the makeup flowrate of triethylene glycol, $\mathrm{HR}$ is the heating requirements of the fired heater, $\mathrm{C}_{\mathrm{NG}}$ is the cost of natural gas, $\mathrm{C}_{\mathrm{TEG}}$ is the cost of triethylene glycol, $\mathrm{C}_{\mathrm{p} \text {,pump }}$ is the purchase cost of the pump, $\mathrm{C}_{\mathrm{p}, \mathrm{FH}}$ is the purchase cost of the fired heater and $\mathrm{C}_{\mathrm{p}, \text { tower, }}$ is the purchase cost of tower. For the heat exchangers and the vessel, the same equations are used. The purchase costs of the towers, pumps, and fire heater were calculated with the following equations.

$$
\begin{gathered}
C_{b m, F H}=F_{b m, F H} C_{p, F H} \\
C_{b m, \text { pump }}=F_{b m, \text { pump }} C_{p, \text { pump }} \\
C_{b m, \text { tower }, n}=F_{b m, \text { column }, n} C_{p, \text { column }, n}+F_{b m, \text { tray }, n} C_{p, \text { tray }, n} \\
\log _{10} C_{p, F H}=2.0829+0.9074 \log _{10}(H R)-0.0243 \log _{10}(H R)^{2} \\
\log _{10} C_{p, \text { pump }}=3.3892+0.0536 \log _{10}\left(P_{\text {pump }}\right)-0.1538 \log _{10}\left(P_{\text {pump }}\right)^{2} \\
\log _{10} C_{p, \text { trays }, n}=2.9949+0.4465 \log _{10}\left(A_{\text {tray }}\right)+0.3961 \log _{10}\left(A_{\text {tray }}\right)^{2}
\end{gathered}
$$

where $\mathrm{A}_{\text {tray }}$ is the area of the tray in $\mathrm{m}^{2}$ and $\mathrm{P}_{\text {pump }}$ is in $\mathrm{kW}$. In calculating the purchase cost of tower $m$, the cost of the column is calculated using the same equations as the vessels above. The bare module factors used are 2 for the trays, 3.24 for the pump and 2.2 for the fire heater.

As mentioned in the main manuscript, these equations were used to determine the minimum cost for dehydrating the flue gas stream to several water levels. An exponential function is then fitted to the data for both dehydration schemes, which is used in the P/VSA model. 


\section{Purity and Recovery Optimization}

Figures S1 and S2 present the internal column profiles corresponding to the highest purity points for zeolite 5A and Ni-MOF-74 as shown in Figure 6. Both of these profiles represent the highest attainable purity while maintaining a $\mathrm{CO}_{2}$ recovery of $90 \%$. The $\mathrm{CO}_{2}$ gas-phase mole fraction, $\mathrm{CO}_{2}$ and $\mathrm{N}_{2}$ molar loadings, and column temperature are shown in Figures S1 and S2.
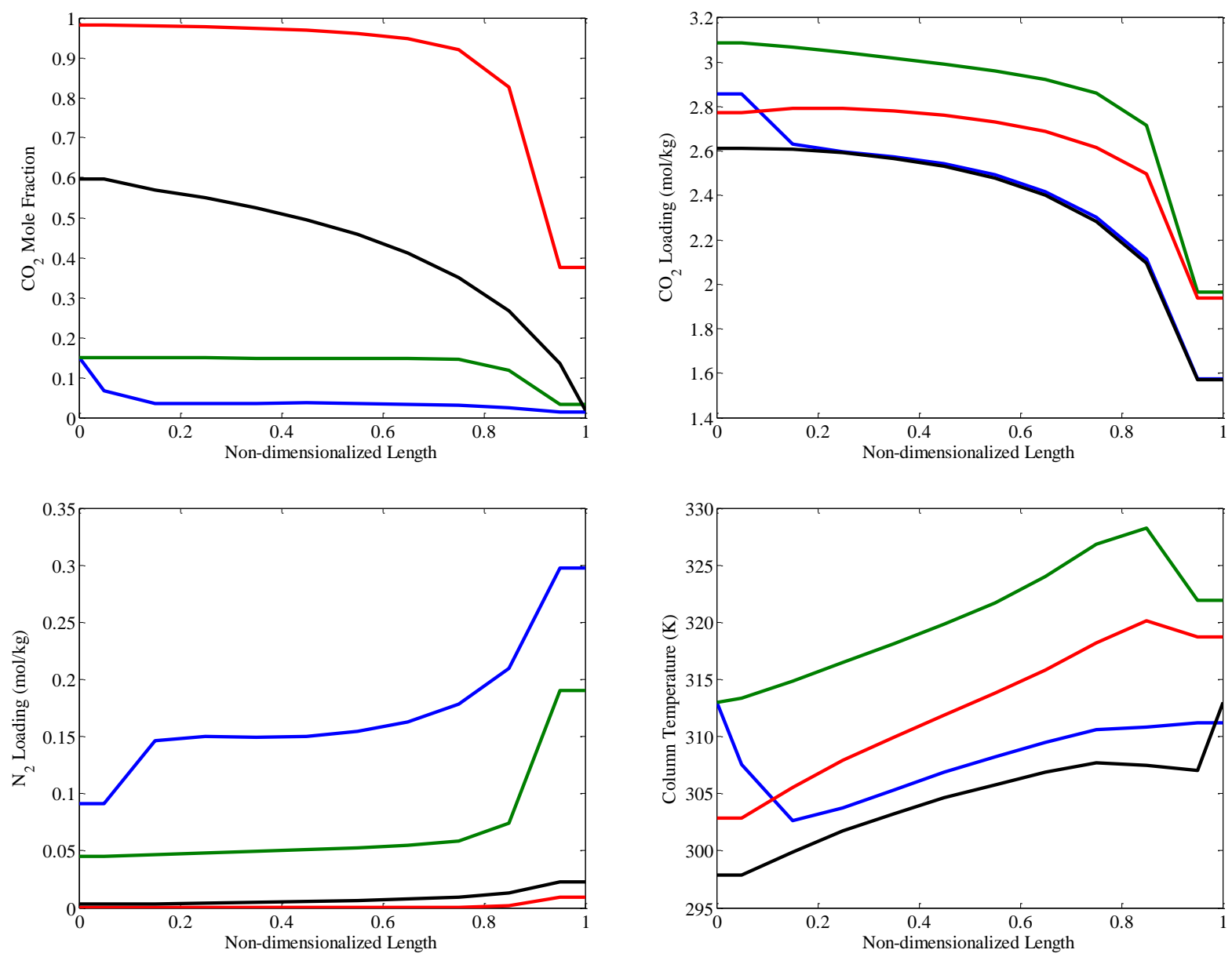

Figure S1. Internal column profile for the highest purity for zeolite 5A shown in Figure 6. Operating parameters for this point are $\mathrm{P}_{\mathrm{H}}=3.1 \mathrm{bar}, \mathrm{t}_{\mathrm{ads}}=837 \mathrm{~s}, \mathrm{t}_{\mathrm{pur}}=816 \mathrm{~s}, \mathrm{~L}=4.18 \mathrm{~m}$. The profiles correspond to the bed at the end of each step with the colors corresponding to Pressurization (Blue), Adsorption (Green), Depressurization (Red), and Purge (Black). 

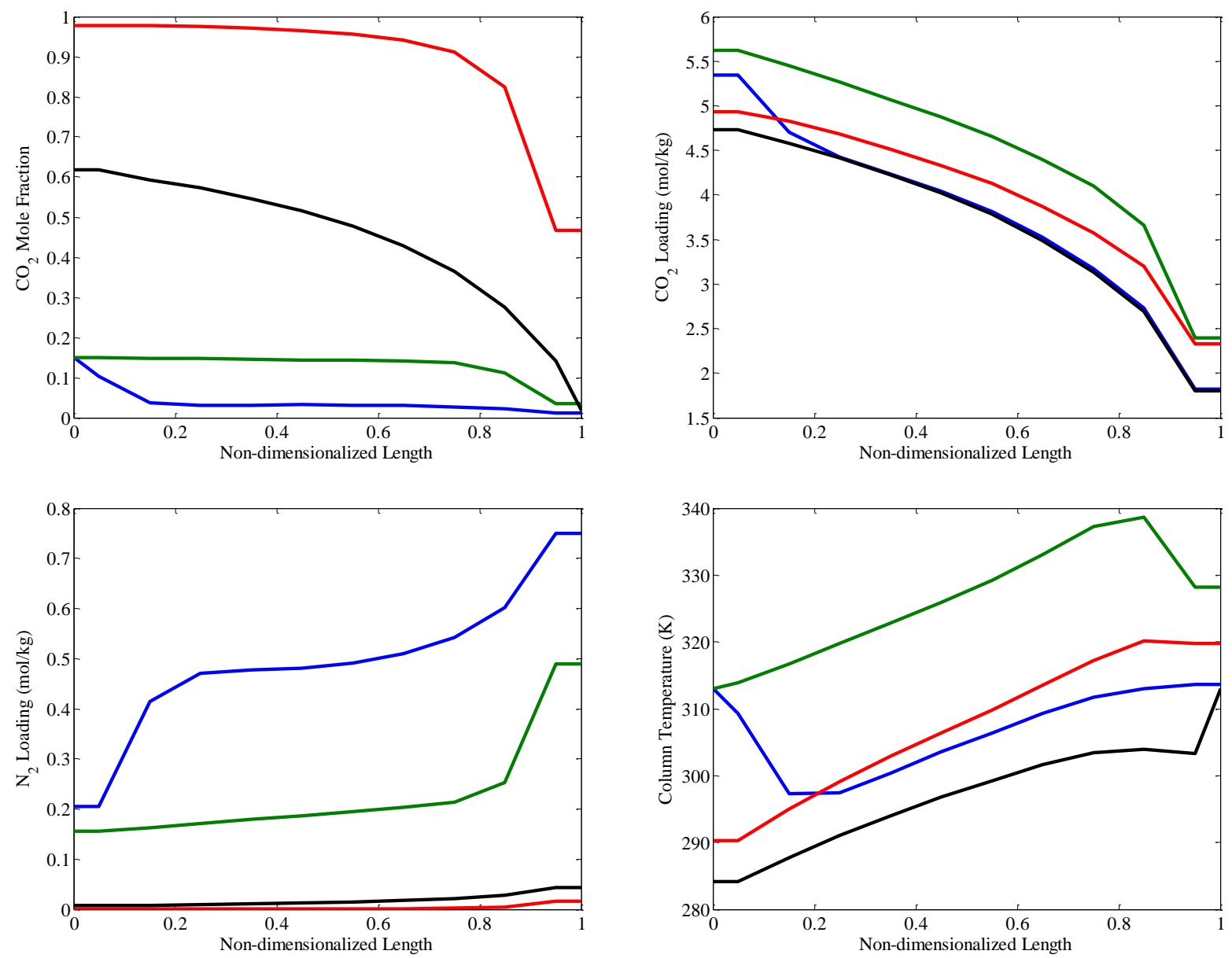

Figure S2. Internal column profile for the highest purity shown in Figure 6 for Ni-MOF-74. Operating parameters for this point are $\mathrm{P}_{\mathrm{H}}=4.2 \mathrm{bar}, \mathrm{tads}_{\mathrm{s}}=703 \mathrm{~s}, \mathrm{t}_{\mathrm{pur}}=684 \mathrm{~s}, \mathrm{~L}=3.17 \mathrm{~m}$. The profiles correspond to the bed at the end of each step with the colors corresponding to Pressurization (Blue), Adsorption (Green), Depressurization (Red), and Purge (Black). 


\section{Dry Flue Gas Economic Optimization}

\section{Required $\mathrm{CO}_{2}$ Purity of $90 \%$}

Figures S3-S8 present the internal profiles for the results described in Tables 3-5. All profiles represent the operating conditions corresponding to the minimum economic cost for obtaining a product stream with a $\mathrm{CO}_{2}$ purity of $90 \%$ and a $\mathrm{CO}_{2}$ recovery of $90 \%$, using dry flue gas as the feed. All results are obtained using the NSGA-II algorithm to minimize the total cost while maintaining the desired product specifications. Additionally, the total energy requirements and the productivity of the P/VSA cycles are given in Table S7.
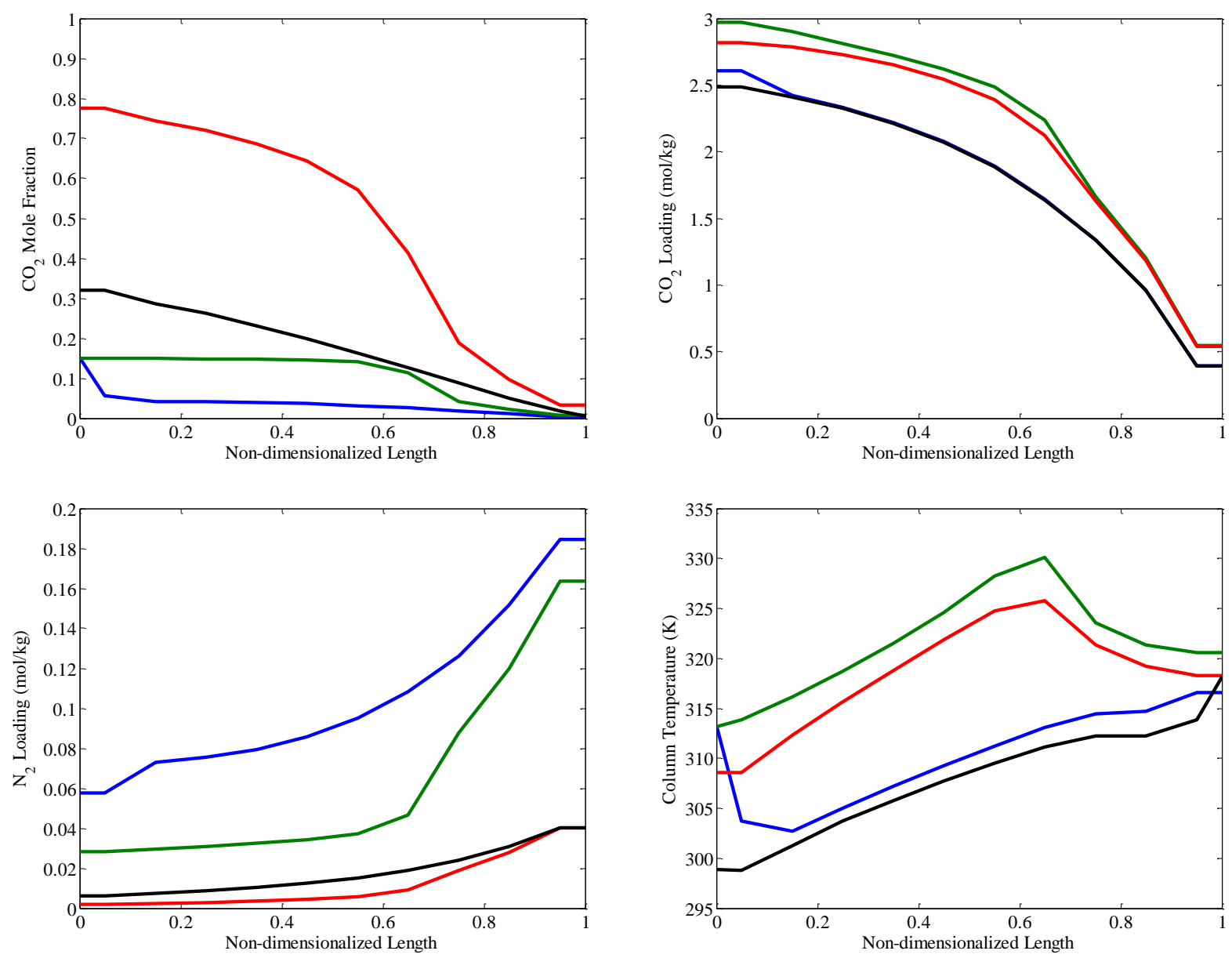

Figure S3. Internal column profile of the $1^{\text {st }}$ stage P/VSA bed for zeolite $13 \mathrm{X}$. The profiles correspond to the bed at the end of each step with the colors corresponding to Pressurization (Blue), Adsorption (Green), Depressurization (Red), and Purge (Black). 

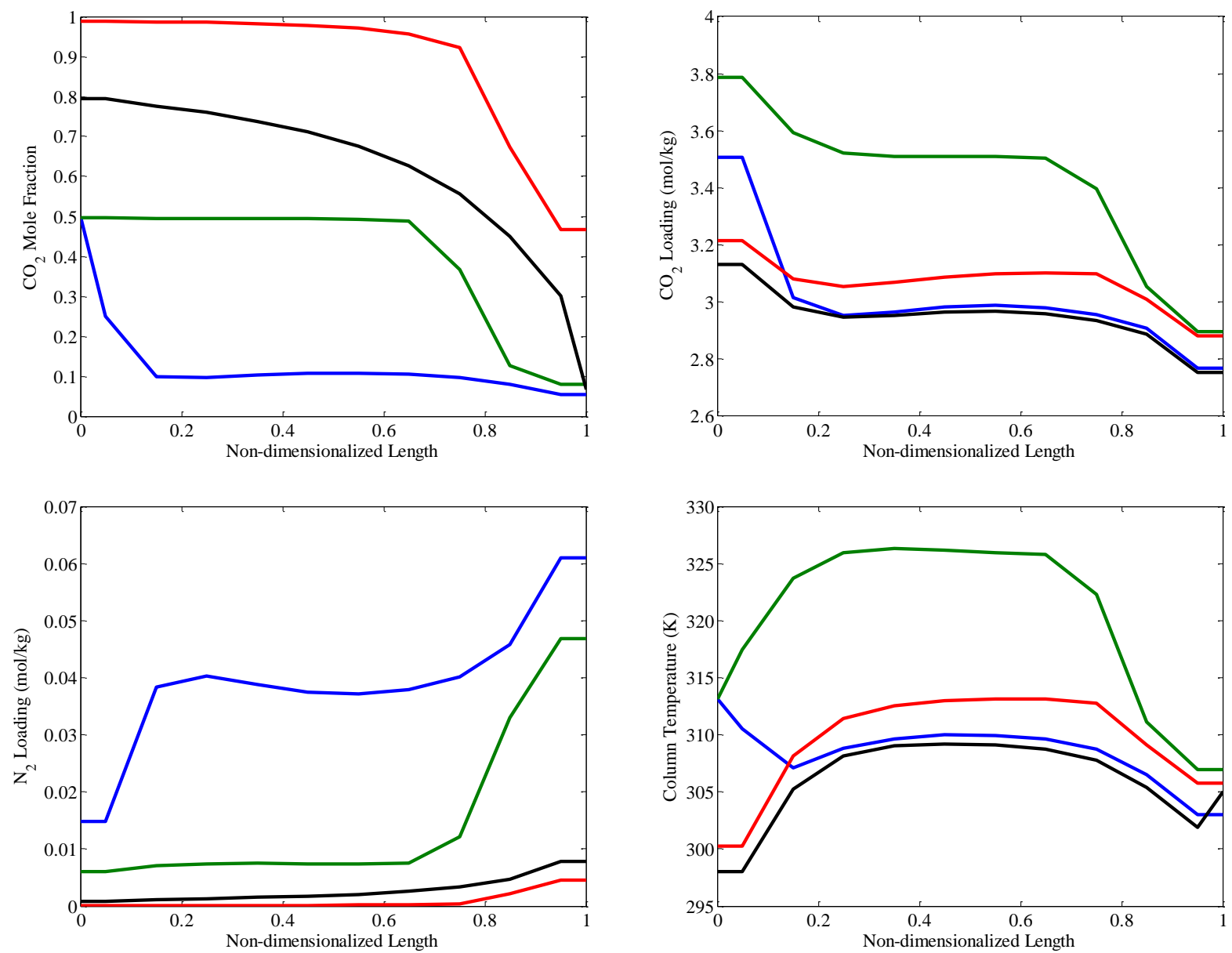

Figure S4. Internal column profile of the $2^{\text {nd }}$ stage P/VSA bed for zeolite $13 X$. The profiles correspond to the bed at the end of each step with the colors corresponding to Pressurization (Blue), Adsorption (Green), Depressurization (Red), and Purge (Black). 

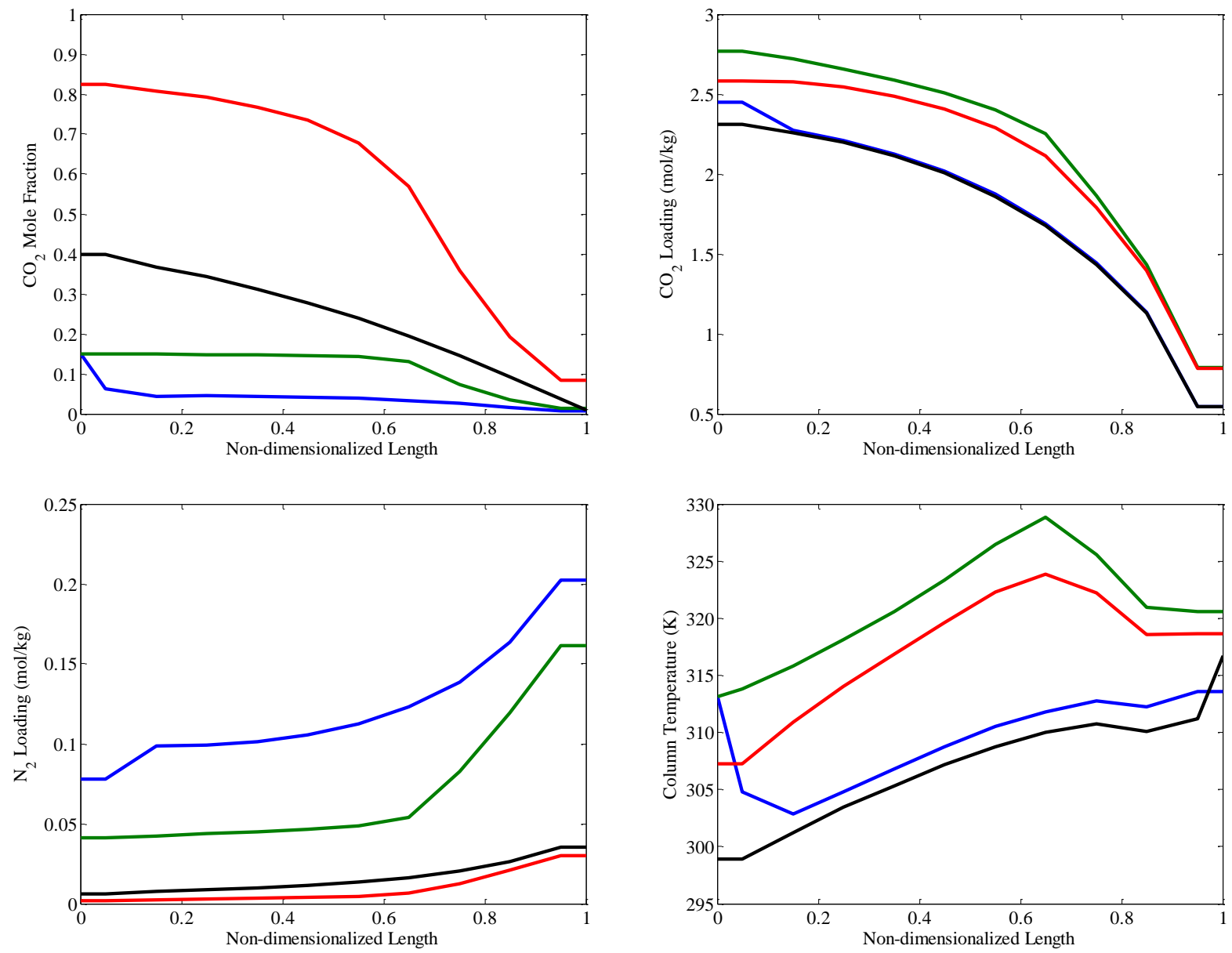

Figure S5. Internal column profile of the $1^{\text {st }}$ stage P/VSA bed for zeolite 5A. The profiles correspond to the bed at the end of each step with the colors corresponding to Pressurization (Blue), Adsorption (Green), Depressurization (Red), and Purge (Black). 

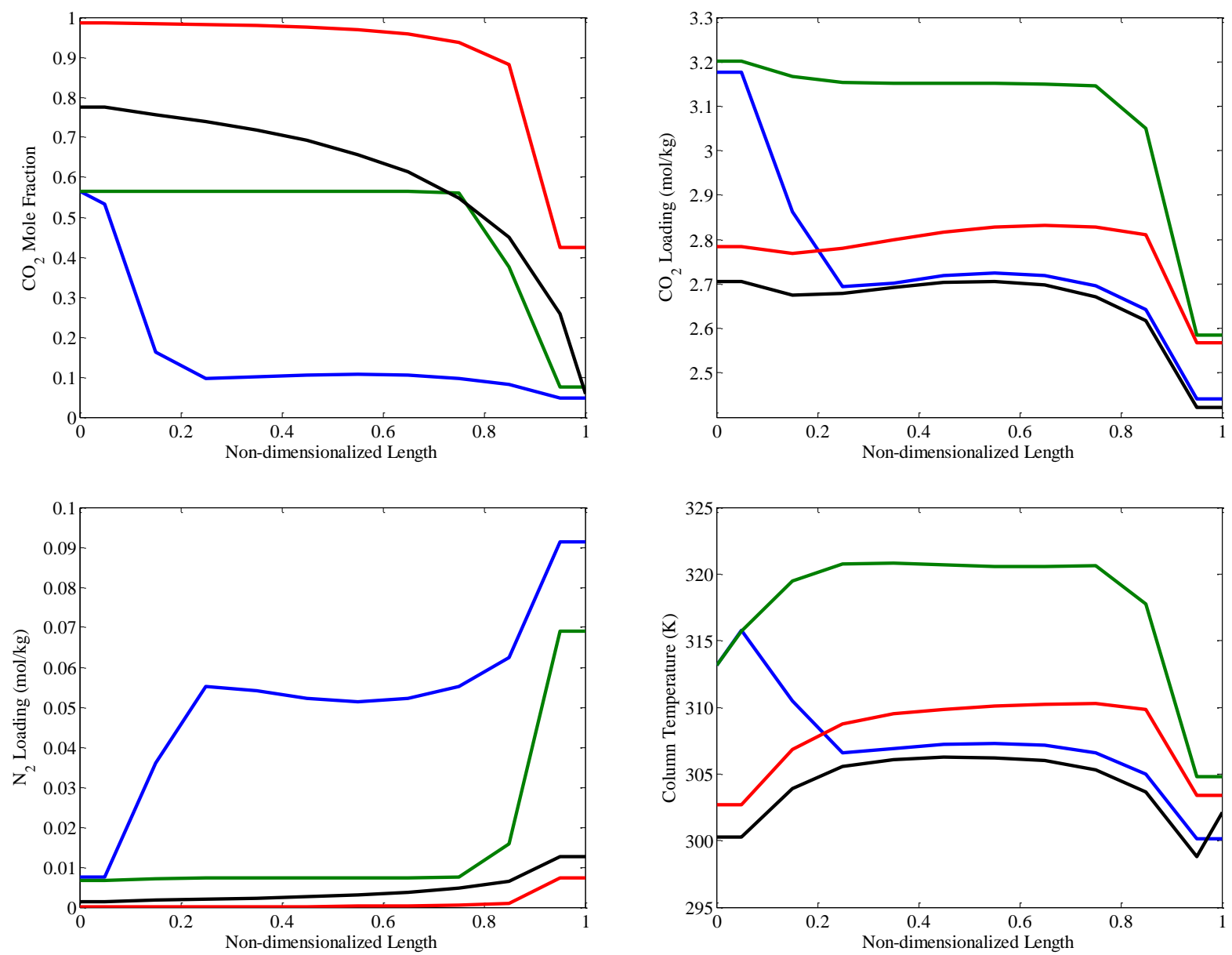

Figure S6. Internal column profile of the $2^{\text {nd }}$ stage P/VSA bed for zeolite 5A. The profiles correspond to the bed at the end of each step with the colors corresponding to Pressurization (Blue), Adsorption (Green), Depressurization (Red), and Purge (Black). 

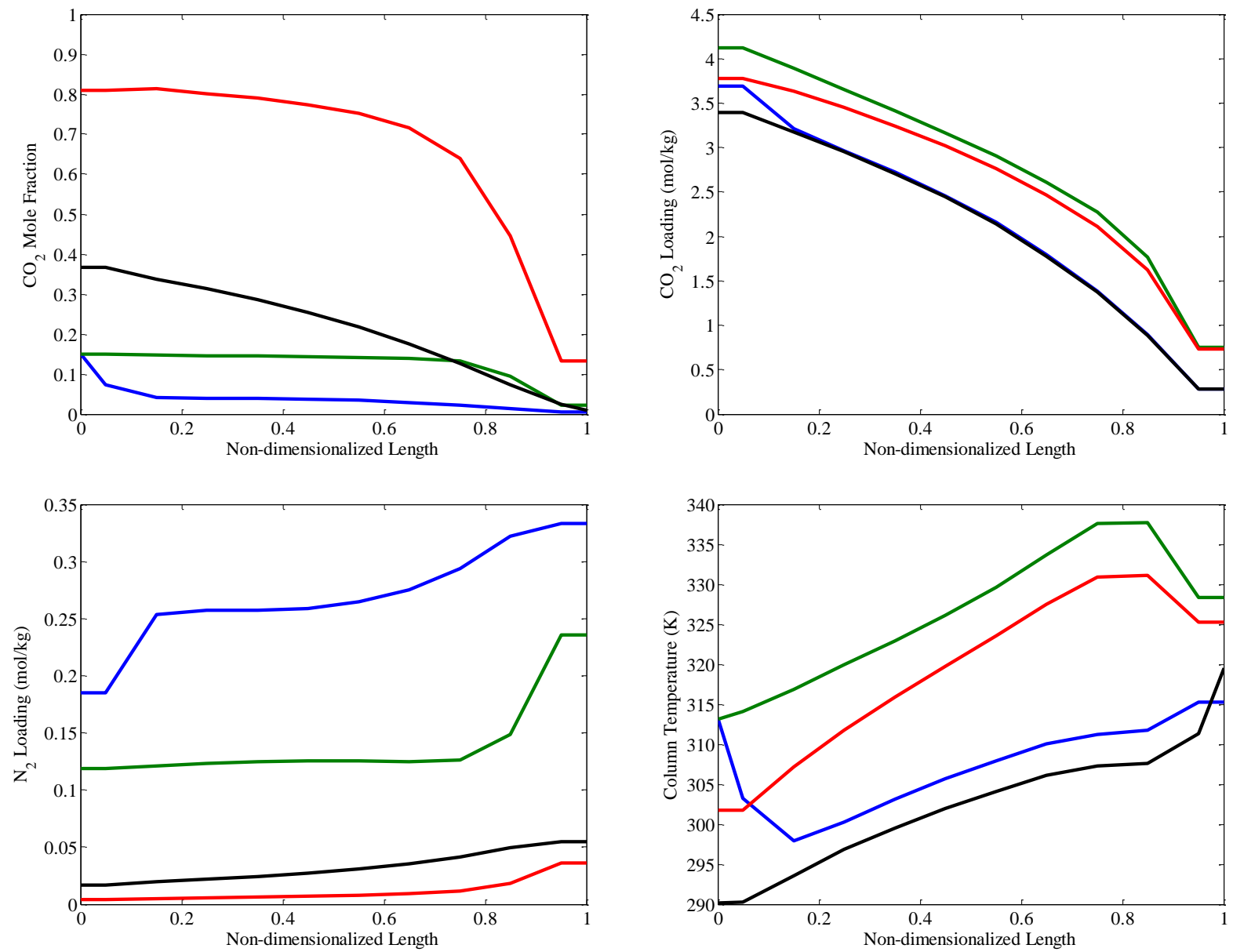

Figure S7. Internal column profile of the $1^{\text {st }}$ stage P/VSA bed for Ni-MOF-74. The profiles correspond to the bed at the end of each step with the colors corresponding to Pressurization (Blue), Adsorption (Green), Depressurization (Red), and Purge (Black). 

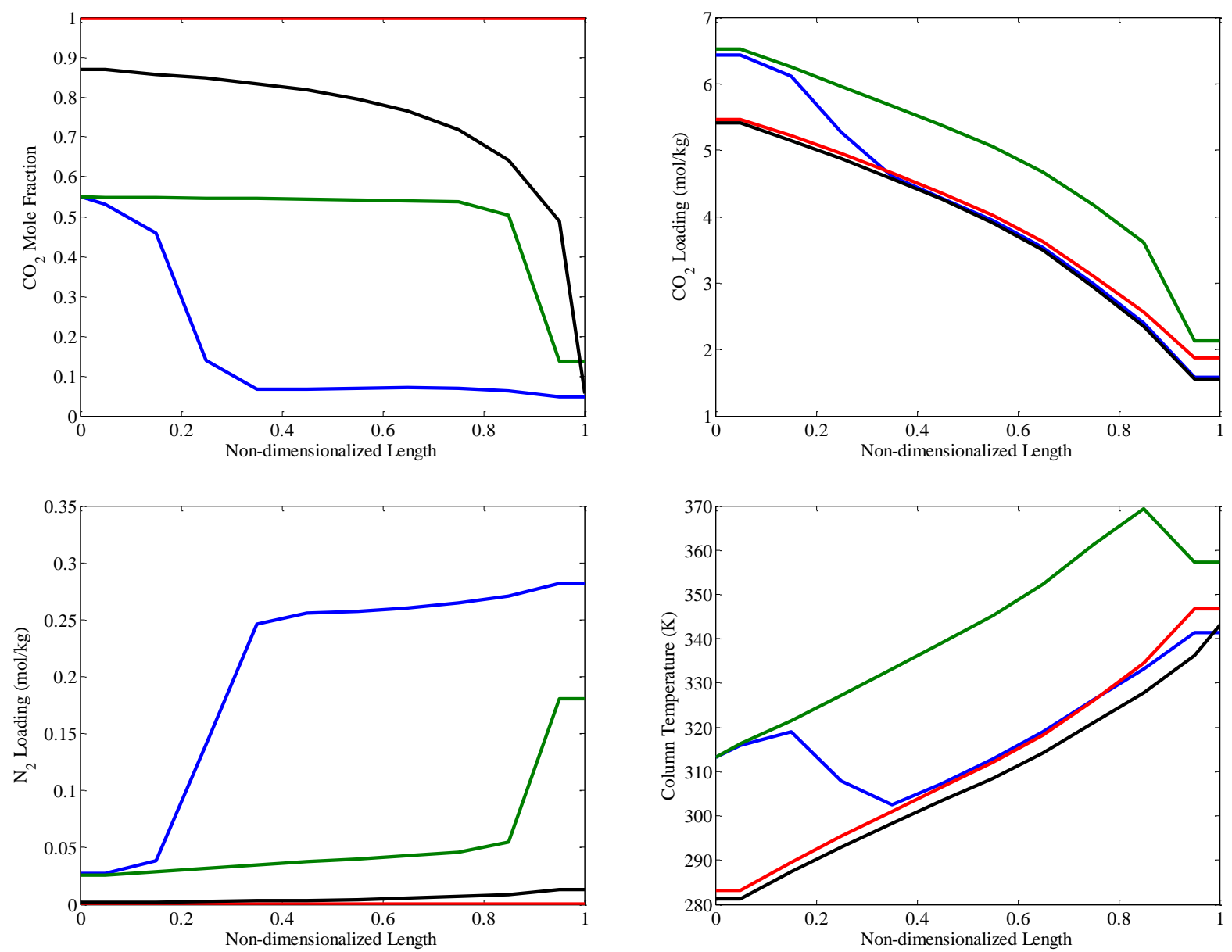

Figure S8. Internal column profile of the $2^{\text {nd }}$ stage P/VSA bed for Ni-MOF-74. The profiles correspond to the bed at the end of each step with the colors corresponding to Pressurization (Blue), Adsorption (Green), Depressurization (Red), and Purge (Black).

Table S7. Energy consumption and productivity of the three P/VSA cycles for the dry flue gas

\begin{tabular}{c|cc}
\hline Material & $\begin{array}{c}\text { Total Energy Consumption } \\
\left(\mathrm{kWh} / \text { ton } \mathrm{CO}_{2}\right)\end{array}$ & $\begin{array}{c}\text { Productivity } \\
\left(\text { ton } \mathrm{CO}_{2} / \mathrm{m}^{3} \text { adsorbent/ day) }\right.\end{array}$ \\
\hline Zeolite 13X & 256.0 & 0.42 \\
Zeolite 5A & 277.8 & 0.43 \\
Ni-MOF-74 & 327.5 & 0.81 \\
\hline
\end{tabular}




\section{Required $\mathrm{CO}_{2}$ Purity of $95 \%$}

The desired purity of $\mathrm{CO}_{2}$ for CCS is sometimes given as $95 \%$. Thus, we ran the same optimization algorithm mentioned above with the $\mathrm{CO}_{2}$ purity set at $95 \%$ and the $\mathrm{CO}_{2}$ recovery maintained at $90 \%$. For this study, we only investigated zeolite $13 \mathrm{X}$ as the adsorbent. Table S8 shows the cost breakdown for these conditions. The operating parameters corresponding to the minimum cost are given in Table S9. Figures S9 and S10 present the internal column profiles of the operating parameters in Table S9. From the cost breakdown, it is apparent that the higher cost of capture for $95 \% \mathrm{CO}_{2}$ purity is due to significantly higher operating costs from the higher compression requirements. The other two sections of the overall cost, annualized capital costs and the post-separation costs, are lower than the $90 \% \mathrm{CO}_{2}$ purity case. For the annualized capital cost, this is due to the higher adsorption pressures. With the higher pressures, a larger amount of flue gas is able to be fed into the column, resulting in a decrease in the size of the columns needed. For the post-separation costs, the lower cost is due to less $\mathrm{N}_{2}$ being compressed to 110 bar.

Table S8. Minimum cost breakdown for 2-stage system with zeolite $13 \mathrm{X}$. Costs are in $\$$ million per year

\begin{tabular}{c|cccccc}
\hline Material & $\begin{array}{c}\text { Operating } \\
\text { Costs }\end{array}$ & $\begin{array}{c}\text { Annualized } \\
\text { Capital } \\
\text { Costs }\end{array}$ & $\begin{array}{c}\text { Post- } \\
\text { Separation } \\
\text { Costs }\end{array}$ & $\begin{array}{c}\text { Total } \\
\text { Costs }\end{array}$ & $\begin{array}{c}\text { Energy } \\
\text { Consumption } \\
\left(\mathrm{kWh} / \text { ton } \mathrm{CO}_{2}\right)\end{array}$ & $\begin{array}{c}\text { Productivity } \\
\text { (ton } \mathrm{CO}_{2} / \mathrm{m}^{3} \\
\text { adsorbent/ day })\end{array}$ \\
\hline $\begin{array}{c}\text { Zeolite } \\
13 \mathrm{X}\end{array}$ & 3.04 & 0.21 & 2.37 & 5.62 & 315.1 & 0.59 \\
\hline
\end{tabular}

Table S9. Optimal operating parameters for the two-stage PSA system. The cycle time is the sum of the times required for each step.

\begin{tabular}{c|cccccc}
\hline Material & $\begin{array}{c}\text { Adsorption } \\
\text { Pressure } \\
(\text { bar })\end{array}$ & $\begin{array}{c}\text { Purge } \\
\text { Pressure } \\
\text { (bar) }\end{array}$ & $\begin{array}{c}\text { Adsorption } \\
\text { Time }(\mathrm{s})\end{array}$ & $\begin{array}{c}\text { Purge } \\
\text { Time }(\mathrm{s})\end{array}$ & $\begin{array}{c}\text { Length } \\
(\mathrm{m})\end{array}$ & $\begin{array}{c}\text { Cycle } \\
\text { Time }(\mathrm{s})\end{array}$ \\
\hline Stage 1 & 1.49 & 0.10 & 637 & 395 & 2.13 & 1113 \\
Stage 2 & 2.76 & 0.13 & 325 & 192 & 4.31 & 806 \\
\hline
\end{tabular}



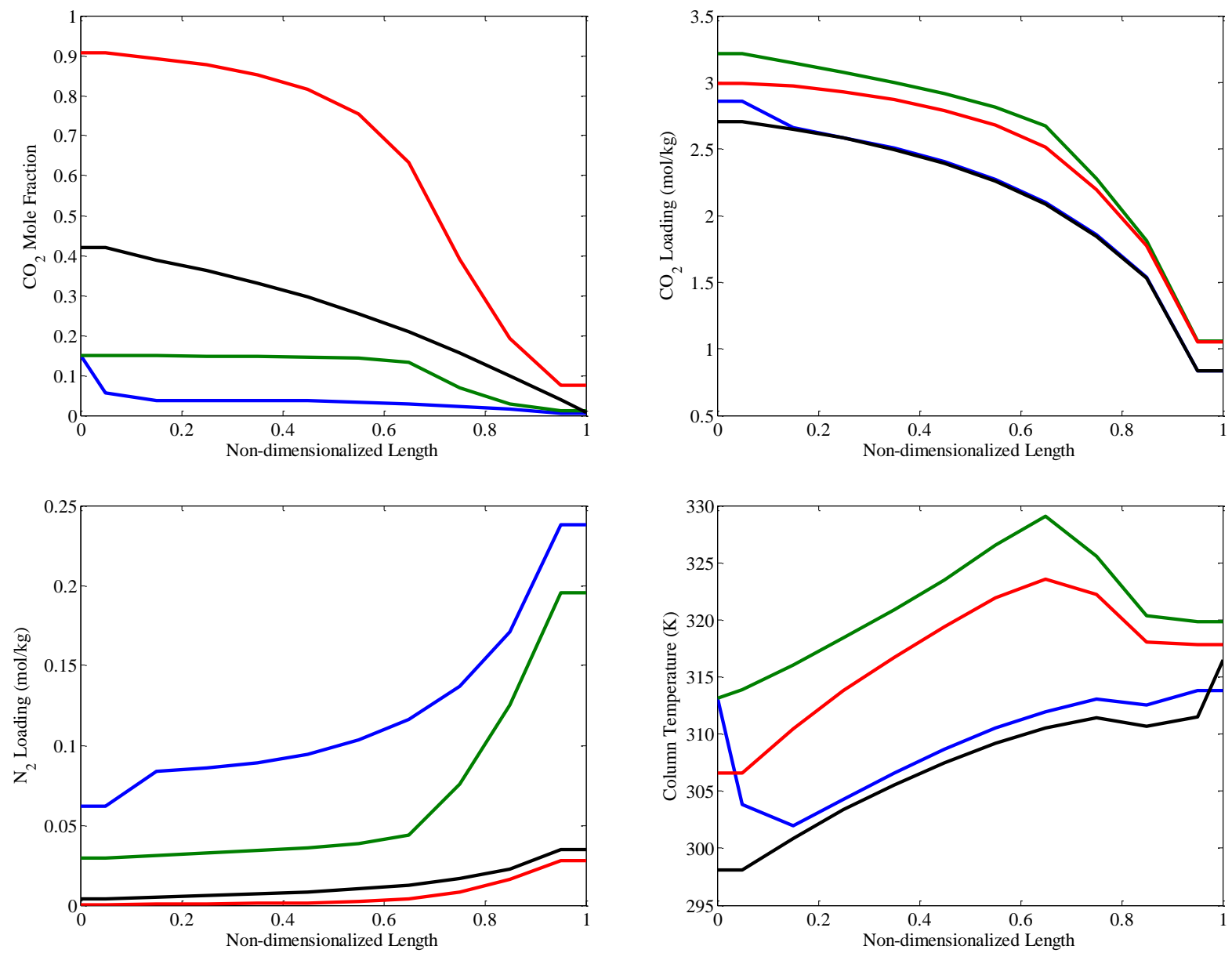

Figure S9. Internal column profile of the $1^{\text {st }}$ stage P/VSA bed for zeolite $13 \mathrm{X}$. The profiles correspond to the bed at the end of each step with the colors corresponding to Pressurization (Blue), Adsorption (Green), Depressurization (Red), and Purge (Black). 

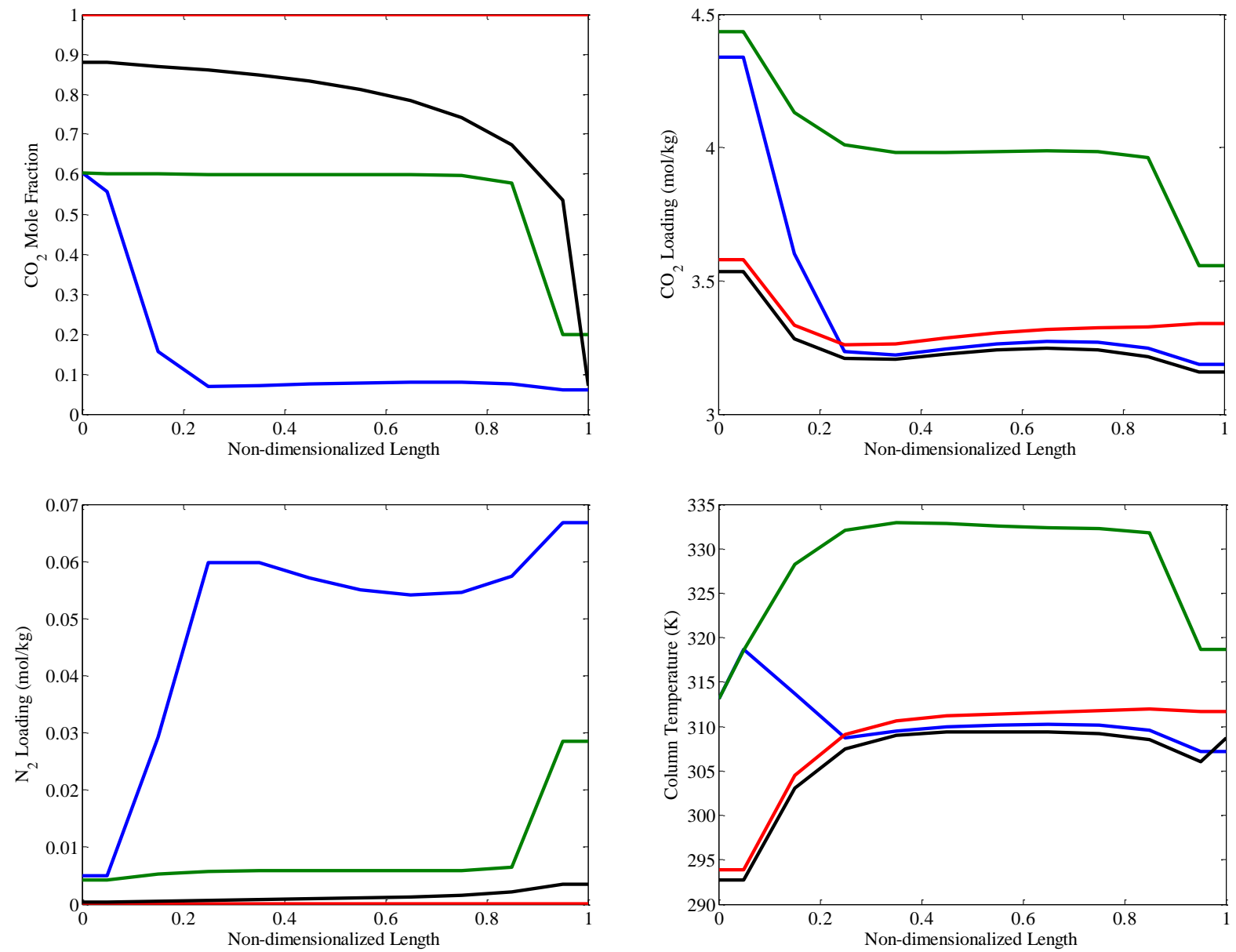

Figure S10. Internal column profile of the $2^{\text {nd }}$ stage P/VSA bed for zeolite $13 X$. The profiles correspond to the bed at the end of each step with the colors corresponding to Pressurization (Blue), Adsorption (Green), Depressurization (Red), and Purge (Black). 


\section{Wet Flue Gas Economic Optimization}

Figures S11-S14 present the internal profiles for the results described in Tables 6-8. All profiles represent the operating conditions corresponding to the minimum economic cost for obtaining a product stream with a $\mathrm{CO}_{2}$ purity of $90 \%$ and a $\mathrm{CO}_{2}$ recovery of $90 \%$, using wet flue gas as the feed. All results are obtained using the NSGA-II algorithm to minimize the total cost while maintaining the desired product specifications. The flue gas was allowed to be dehydrated before being fed into the column using either Cooling and Condensation or TEG absorption technologies seen in Figures 3 and 4. This allows the water level of the entering flue gas to vary from $0.01 \mathrm{~mol} \%$ to $5.5 \mathrm{~mol} \%$. Additionally, the total energy requirements and the productivity of the P/VSA cycles are given in Table S10.
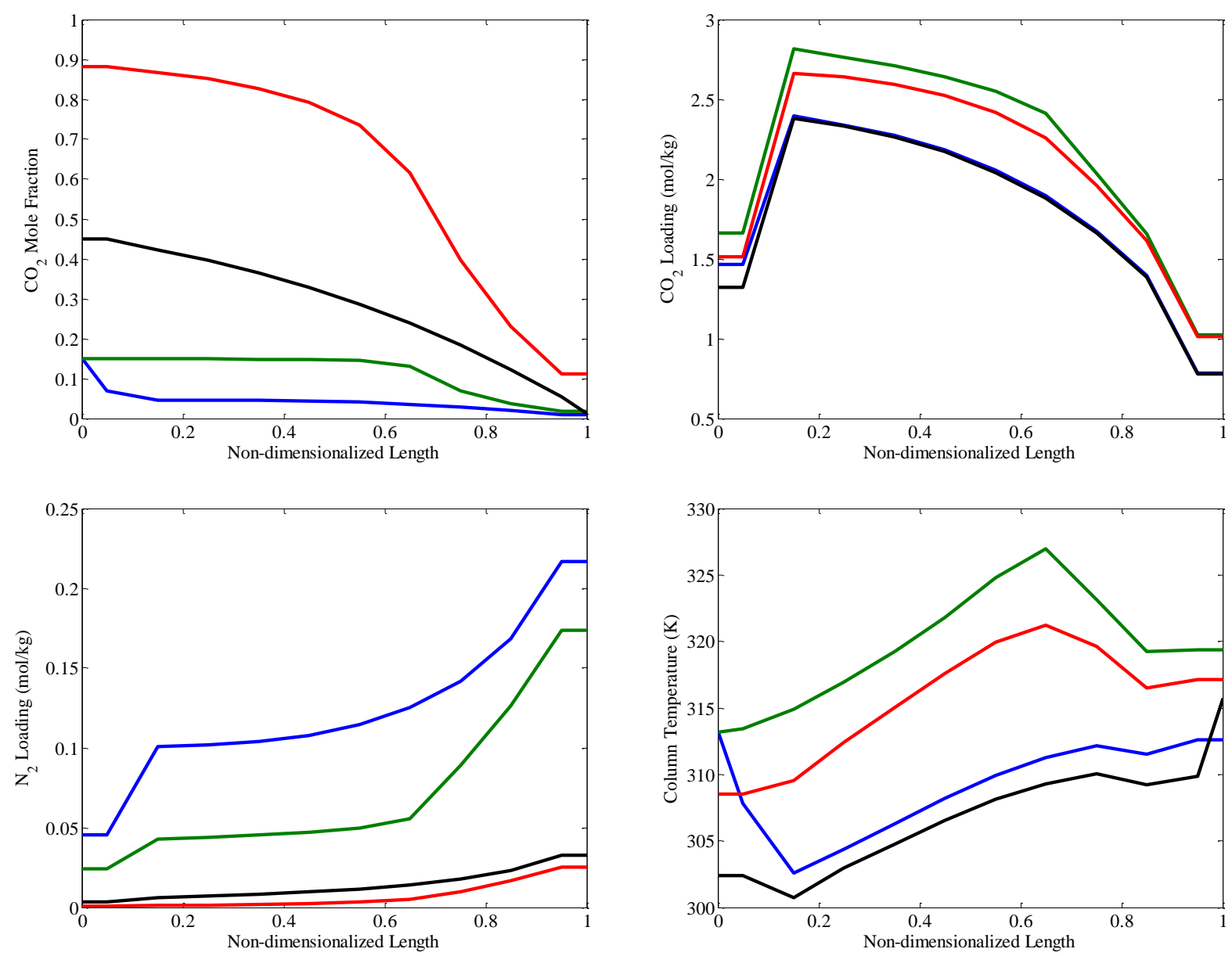

Figure S11. Internal column profile of the $1^{\text {st }}$ stage P/VSA bed for zeolite 5A. The profiles correspond to the bed at the end of each step with the colors corresponding to Pressurization (Blue), Adsorption (Green), Depressurization (Red), and Purge (Black). 

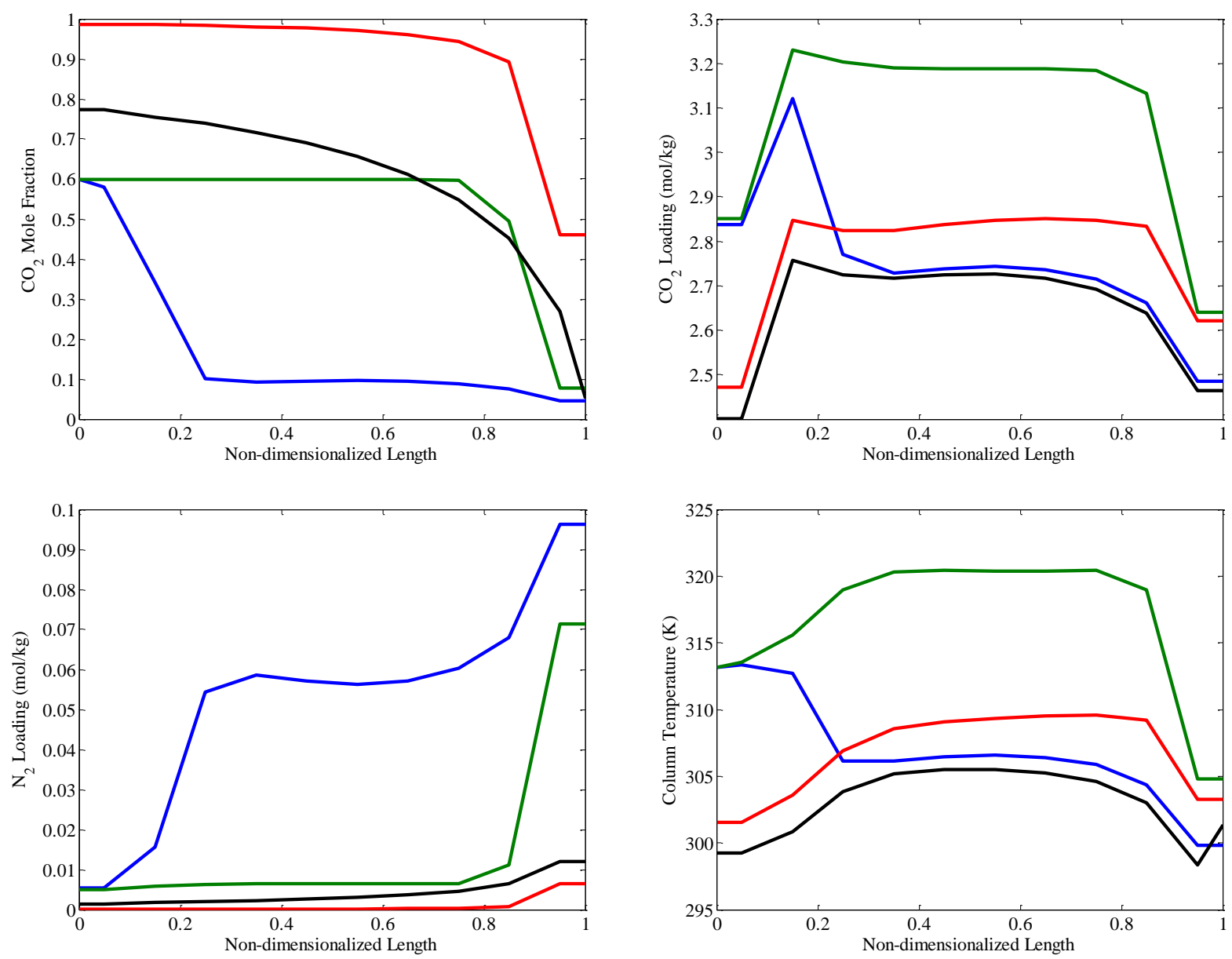

Figure S12. Internal column profile of the $2^{\text {nd }}$ stage P/VSA bed for zeolite $5 \mathrm{~A}$. The profiles correspond to the bed at the end of each step with the colors corresponding to Pressurization (Blue), Adsorption (Green), Depressurization (Red), and Purge (Black). 

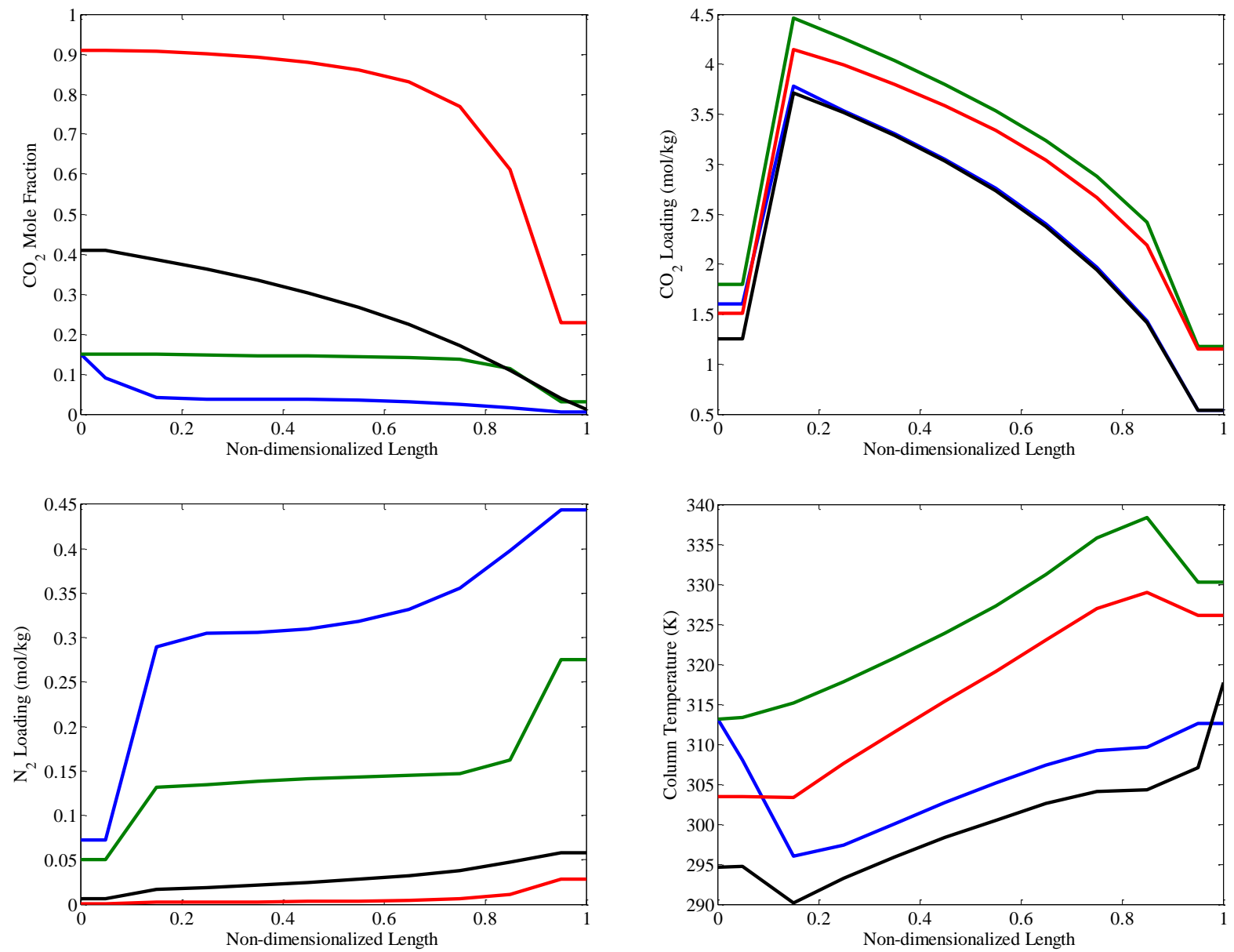

Figure S13. Internal column profile of the $1^{\text {st }}$ stage P/VSA bed for Ni-MOF-74. The profiles correspond to the bed at the end of each step with the colors corresponding to Pressurization (Blue), Adsorption (Green), Depressurization (Red), and Purge (Black). 

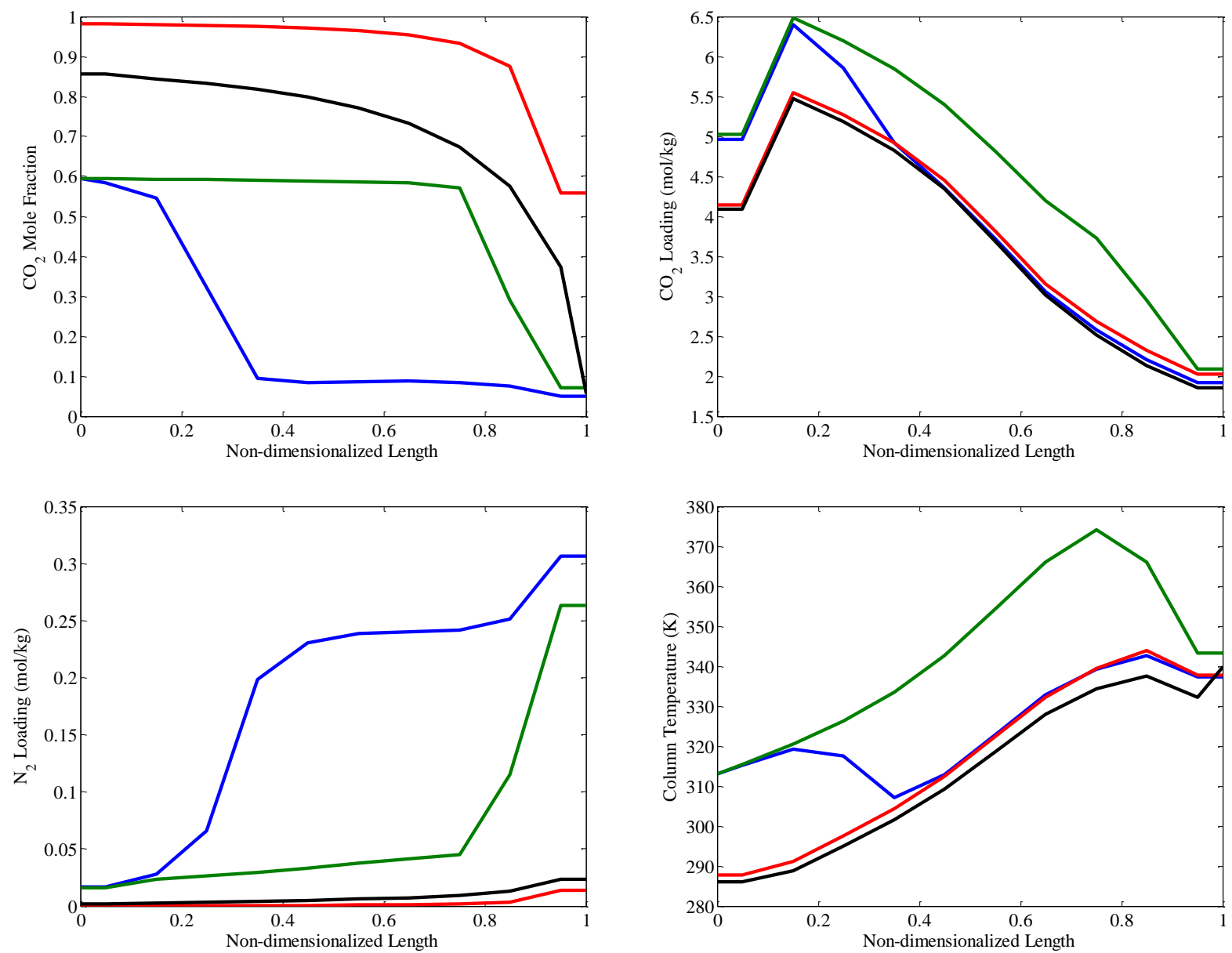

Figure S14. Internal column profile of the $2^{\text {nd }}$ stage P/VSA bed for Ni-MOF-74. The profiles correspond to the bed at the end of each step with the colors corresponding to Pressurization (Blue), Adsorption (Green), Depressurization (Red), and Purge (Black).

Table S10. Energy consumption and productivity of the three P/VSA cycles for the wet flue gas

\begin{tabular}{c|cc}
\hline Material & $\begin{array}{c}\text { Total Energy Consumption } \\
\left(\mathrm{kWh} / \text { ton } \mathrm{CO}_{2}\right)\end{array}$ & $\begin{array}{c}\text { Productivity } \\
\left(\text { ton } \mathrm{CO}_{2} / \mathrm{m}^{3} \text { adsorbent/ day) }\right.\end{array}$ \\
\hline Zeolite 13X & 275.7 & 0.27 \\
Zeolite 5A & 293.3 & 0.47 \\
Ni-MOF-74 & 361.7 & 0.84 \\
\hline
\end{tabular}

\section{References}

(1) Turton, R.; Bailie, R. C.; Whiting, W. B.; Shaeiwitz, J. A.; Bhattacharyya, D. Analysis, Synthesis, and Design of Chemical Processes; Prentice Hall: Upper Saddle River, NJ, 2012. 